\title{
Production of Sonali chicken in selected areas of Gazipur district - an economic study
}

\author{
MT Uddin*, SJ Mitu, I A Begum
}

Department of Agricultural Economics, Bangladesh Agricultural University, Mymensingh 2202, Bangladesh

\begin{abstract}
This study attempts to conduct an economic analysis and resource use efficiency for Sonali chicken production covering five villages of Sadar Upazila under Gazipur district. Primary data were collected from 60 purposively selected Sonali chicken rearers for this study. Descriptive and functional analysis were employed to achieve the objectives of the study. The major findings of the study are that total cost for 1000 birds were estimated at Tk. 120613 per batch. Average gross margin and average net returns for 1000 birds was calculated at Tk. 57240 and Tk. 52059 per batch. An average gross return for 1000 birds was estimated at Tk. 172672 per batch. Benefit cost ratio was found 1.4 for Sonali chicken production. Labour, veterinary and medicine and electricity cost had positive and significant impact on Sonali chicken production. Resource use efficiency was calculated by the ratio of marginal value product and marginal factor cost. Finally, the study also identified some of the major problems associated with Sonali chicken farming and suggested some possible steps for overcoming these problems.
\end{abstract}

Key words: Benefit cost ratio, Cobb-Douglas production function, Sonali chicken

Bangladesh Animal Husbandry Association. All rights reserved.

Bang. J. Anim. Sci. 2014. 43 (1): 56-61

\section{Introduction}

Bangladesh is an agro-based developing country and the growth and sustainability of agricultural production are prerequisite for attaining the rate of overall growth of the economy. Livestock is an important sub-sector of agriculture. Poultry is one of the major components of livestock sub-sectors that committed to supply cheap sources of good quality nutritious animal protein to the nation. Poultry farming has turned out to be promising dynamic enterprise with enormous potential for rapid poverty reduction in Bangladesh. Poultry farming provides a substantial economic contribution and generates self-employment opportunities for the unemployed youth generation. A noticeable development has been taken place in poultry farming in Bangladesh. Table 1 shows the growth trend of the poultry population of Bangladesh over the past few years. It is observed from the table that the increasing rate is satisfactory throughout the period with little exception.

The overall contribution of the broad agriculture sector at constant price was 19.95 percent of GDP in 2010/11 (BER 2011). In agriculture sector, contribution of crops, livestock and forestry were 11.24, 2.57 and $1.71 \%$, respectively. Commercial or intensive poultry farming has now turned into a profitable business in Bangladesh. Poultry industry in Bangladesh has made significant progress during the last two decades where commercial poultry started in 1980 in Bangladesh. Chowdhury (2013) stated that commercial poultry increased significantly during 1980-1990 (6\%) and 1990-2000 (8\%) in this country.

Sonali chicken, the crossbred of Fayoumi female and RIR (Rhode Island Red) male developed in 1986, has been reported to perform better with respect to egg and meat production, rapid growth and low mortality under scavenging, semiscavenging and intensive farming system. It has been taking its place besides the indigenous hens due to its adaptability and acceptability in the climatic conditions of Bangladesh. Sonali, with a phenotypic appearance similar to local chicken has higher market demand than exotic breed. As an important segment of livestock production, the Sonali chicken industry in Bangladesh is considered a great avenue for the economic growth and simultaneously creates numerous employment opportunities. About 76 percent of Sonali beneficiary has improved their conditions by rearing this type of poultry (Hossen et al. 2012). 
Uddin et al. (2014) Bang. J. Anim. Sci. 43 (1): 56- 61

Table 1. Numbers of poultry in Bangladesh

\begin{tabular}{lccccc}
\hline \multirow{2}{*}{ Year } & \multicolumn{2}{c}{ Number of poultry birds (in lakh) } & \multicolumn{2}{c}{ Production of meat and egg } \\
\cline { 2 - 5 } & Chicken & Duck & Total Poultry & Meat (Lakh tones) & Egg (in lakh) \\
\hline $2004-05$ & 1836.50 & 372.80 & 2207.30 & 10.60 & 56230 \\
$2005-06$ & 1948.20 & 381.70 & 2329.90 & 11.30 & 54220 \\
$2006-07$ & 2068.90 & 390.80 & 2459.70 & 10.40 & 53690 \\
$2007-08$ & 2124.70 & 398.40 & 2523.10 & 10.40 & 56532 \\
$2008-09$ & 2213.94 & 412.34 & 2626.28 & 10.84 & 46920 \\
$2009-10$ & 2280.35 & 426.77 & 2707.12 & 12.64 & 57424 \\
$2010-11$ & 2346.86 & 441.20 & 2788.06 & 12.79 & 42110 \\
$2011-2012$ & 2392.49 & 451.15 & 22843.64 & 16.92 & 40561 \\
\hline
\end{tabular}

Source: BER 2011

Bangladesh reportedly is turning to be a society of sick, stunted and degenerated bunch of people due to chronic protein deficiency. This country has already marked for its poverty, external dependence and unemployment problem. In this circumstance, Sonali chicken farming would be an excellent and appropriate way to promote the nutritional and economic security of the people living in rural, tribal and inaccessible areas in a sustainable manner. Sonali chicken production provides higher returns to the farmers. This enterprise is gaining popularity in the country gradually due to its high yield potentiality, although proper management and appropriate level of input use are important for achieving such higher yield and profits.

Some researches have been conducted about hatchability, fertility, growth rate and mortality rate of Sonali chicken and a few researches have been done on the comparative analysis of Sonali chicken breed with other poultry breeds. Saleque and Saha (2013) conducted a study on production and economic performance of small scale Sonali bird farming for meat production in Bangladesh; Hossen et al. (2012) conducted a study on the problems and prospects of Sonali chicken farming in different village levels of Joypurhat district in Bangladesh; Miazi et al. (2012) examined a study on fertility and hatchability of Fayoumi and Sonali chicks. However, the present research explores information on the economic aspects of Sonali chicken farming which is indeed a new study in the poultry industry. This study is very important in terms of producing meaningful information to uplift the productivity and to ensure the sustainability of Sonali chicken industry. The overall objective of the study is to estimate the profitability of Sonali chicken production and the efficiency of resources used for such production.

\section{Materials and Methods}

Study areas were selected from Gazipur Sadar Upazila under Gazipur district. A purposive sampling technique was followed in the study. A total of 60 samples were interviewed for collection of necessary data. A structured questionnaire was prepared for that purpose. Primary data were collected from the Sonali chicken farm owners by applying field survey method. Secondary data and information were collected from various journals, bulletins, government publications as well as from different organizations such as Bangladesh Bureau of Statistics, Bangladesh Economic Review, etc. For analyzing the data, a combination of tabular and statistical techniques were used to achieve the objectives and to get meaningful results. In the study, the following equation was used to calculate profitability of Sonali chicken farming:

$\boldsymbol{\Pi}=\left(\boldsymbol{P}_{\mathrm{m}} \mathbf{Q}_{\mathrm{m}}+\mathbf{P}_{1} \mathbf{Q}_{1}\right)-\left(\Sigma\left(P_{\mathrm{xi}} \cdot \mathbf{X}_{\mathrm{i}}\right)+\mathrm{TFC}\right)$

where,

$\Pi=$ Profit per Sonali chicken farm (Tk./batch);

$P_{m}=$ Per unit price of output (Tk.);

$\mathrm{Q}_{\mathrm{m}}=$ Number/Quantity of output;

$\mathrm{P}_{1}=$ Per unit price of used litter and excreta (sack/per batch);

$\mathrm{Q}_{2}=$ Quantity of waste litter and excreta (sack/per batch);

$\mathrm{P}_{\mathrm{xi}}=$ Per unit price of the variables inputs;

$X_{i}=$ Number/ Quantity of ith inputs;

$\mathrm{i}=(1,2,3 \ldots \mathrm{n})$; and

TFC $=$ Total fixed cost.

To explore the input-output relationship of Sonali chicken production, the following Cobb-Douglas production function models was used:

$Y=a X_{1}^{b 1} X_{2}^{b 2} \quad X_{3}{ }^{b 3} \quad X_{4}{ }^{b 4} X_{5}{ }^{b 5} X_{6}{ }^{b 6} U_{i}$

The above function was linearized as follows: 


\section{Sonali chicken production}

$\ln Y=\ln a+b_{1} \ln X_{1}+b_{2} \ln X_{2}+b_{3} \ln X_{3}+b_{4}$ $\ln X_{4}+b_{5} \ln X_{5}+b_{6} \ln X_{6}+U_{i}$

where,

$Y=$ Gross return from Sonali chicken production (Tk.);

$\mathrm{X}_{1}=$ Cost of day-old-chick (Tk.);

$\mathrm{X}_{2}=$ Cost of feed (Tk.);

$X_{3}=$ Labour cost (Tk.);

$\mathrm{X}_{4}=$ Medicine and veterinary cost (Tk.);

$\mathrm{X}_{5}=$ Electricity cost (Tk.);

$\mathrm{X}_{6}=$ Litter cost $(\mathrm{Tk}$.$) ;$

$b_{1}-b_{6}=$ Co-efficients of the relevant variables;

In = Natural logarithm;

$\mathrm{U}_{\mathrm{i}}=$ Disturbance term; and

$\mathrm{a}=$ Intercept.

Moreover, the MVP and the MFC comparison was done to measure the efficiency or inefficiency of the resources used in Sonali chicken production. Since six variables of the regression model were measured in monetary value, the slope of coefficients of those explanatory variables in the function represented the MVPs which were calculated by multiplying the production coefficient of given resources with the ratio of geometric mean (GM) of the given resources, i.e.,

In $Y=\ln a+b_{i} \ln X_{i}$

$$
\frac{d y}{d X i}=b i \frac{Y}{X i}
$$

Therefore,

$\operatorname{MVP}(\mathrm{Xi})=$ bi $\frac{\bar{Y}(G M)}{\bar{X}_{i}(G M)}$

where,

$\bar{Y}=$ Mean of gross return (geometric mean);

$\bar{X}_{i}=$ Mean of $\mathrm{i}^{\text {th }}$ variable input (geometric mean); $\mathrm{i}=1,2$, 3, 4, 5 and 6; GM = Geometric mean; and $\mathrm{dy} / \mathrm{dx}=$ Slope of production function as well as MVP of input.

\section{Results and Discussions}

\section{Profitability of Sonali chicken Production}

In the study area, farmers reared Sonali chicken in different numbers. As the maximum farmers reared Sonali chicken was around 1000 number, the cost return calculation as well as the production function was applied for that specific number i.e. for 1000 birds. The different numbers and percentage of Sonali chicken farmers are shown in Table 2.

Table 2. Farm sizes based on number of Sonali chicken rearing

\begin{tabular}{lcc}
\hline No. Sonali chicken & No. farms & $\%$ \\
\hline $0-1000$ & 24 & 40.0 \\
$1001-2000$ & 6 & 10.0 \\
$2001-3000$ & 4 & 6.6 \\
$3001-4000$ & 6 & 10.0 \\
$4001-5000$ & 3 & 5.0 \\
$5001-6000$ & 3 & 5.0 \\
$6001-7000$ & 4 & 6.6 \\
$7001-8000$ & 5 & 8.3 \\
$8001-9000$ & 3 & 5.0 \\
$9001-10000^{+}$ & 2 & 3.3 \\
\hline Total & 60 & 100 \\
\hline
\end{tabular}

Source: Field survey 2013

The total cost of rearing Sonali chicken for 1000 birds was estimated at Tk. 120613. The respective average variable costs and fixed costs for 1000 birds were calculated at Tk. 115432 and Tk. 5181 per batch. Interest on operating capital was computed at the rate of 12.0 percent for a year (Table 3).

Table 3. Total costs of Sonali chicken production for 1000 birds

\begin{tabular}{lcc}
\hline Particulars & Costs (Tk.) & $\%$ \\
\hline Variable cost & & \\
Day old chick cost & 29846 & 24.7 \\
Feed cost & 71798 & 59.5 \\
Labour cost & 2198 & 1.8 \\
Veterinary and & 8728 & 7.2 \\
medicine cost & & \\
Electricity cost & 712 & 0.6 \\
Litter cost & 1489 & 1.2 \\
Repairing cost & 661 & 0.6 \\
A .Total variable cost & 115432 & 95.6 \\
Fixed cost & & \\
Depreciation cost & 1360 & 1.1 \\
Family labour cost & 2667 & 2.2 \\
Interest on operating & 1154 & 1.0 \\
capital & & \\
$\quad$ B. Total fixed cost & 5181 & 4.3 \\
Total cost (A+B) & 120613 & 100.0 \\
\hline
\end{tabular}

Source: Authors' calculation based on field survey, 2013 
Gross return was determined by adding income earned from sale of live Sonali chicken, used litter and bird excreta. It is evident from Table 4 that the average gross returns for 1000 birds were Tk. 172672 where average return from meat was Tk. 169760 and average return from litter was Tk. 2912.

Table 4. Gross return from Sonali chicken production for 1000 birds

\begin{tabular}{lcc}
\hline Particulars & Return (Tk.) & $\%$ \\
\hline Meat & 169760 & 98.3 \\
Litter & 2912 & 1.7 \\
Total & 172672 & 100.0 \\
\hline
\end{tabular}

Source: Authors' calculation based on field survey 2013

Average gross margins and average net returns for 1000 birds were at Tk. 57240 and Tk. 52059, respectively. Benefit-cost ratio of Sonali chicken farming was 1.4 (Table 5). Saleque and Saha (2013) also conducted a study on Sonali chicken for meat production. In that study, BCR was calculated for two different areas as 1.19 and 1.18 in Joypurhat and Bogra, respectively.

Table 5. Gross margin and gross return for Sonali chicken farm for 1000 birds

\begin{tabular}{ll}
\hline Particulars & Value (Tk.) \\
\hline A. Gross return & 172672 \\
B. Total variable cost & 115432 \\
C. Total fixed cost & 5181 \\
D. Total cost (B+C) & 120613 \\
Gross margin (A-B) & 57240 \\
Net return (A-D) & 52059 \\
BCR (undiscounted) (A/D) & 1.4 \\
\hline Source: Authors' calculation & based on field \\
survey, 2013. &
\end{tabular}

\section{Production Functional Analysis}

For quantifying the impacts of the selected variables on the returns from Sonali chicken production, Cobb-Douglas production function model was estimated. The results of estimation of the model for Sonali chicken production are presented in Table 6.
Table 6. Estimated coefficient values and related statistics of Cobb-Douglas Production function of Sonali chicken production

\begin{tabular}{lccc}
\hline Explanatory variables & $\begin{array}{c}\text { Value of } \\
\text { coefficient }\end{array}$ & SE & $\begin{array}{c}\text { T- } \\
\text { value }\end{array}$ \\
\hline Intercept & 11.951 & 0.191 & 62.480 \\
Day-old-chick cost $\left(\mathrm{X}_{1}\right)$ & 0.196 & 0.355 & 0.553 \\
Feed cost $\left(\mathrm{X}_{2}\right)$ & 0.498 & 0.968 & 0.516 \\
Labour cost $\left(\mathrm{X}_{3}\right)$ & $0.075^{* *}$ & 0.035 & 2.143 \\
Veterinary cost $\left(\mathrm{X}_{4}\right)$ & $0.081^{*}$ & 0.058 & 1.897 \\
Electricity cost $\left(\mathrm{X}_{5}\right)$ & $0.058^{* *}$ & 0.027 & 2.149 \\
Litter cost $\left(\mathrm{X}_{6}\right)$ & 0.186 & 0.393 & 0.475 \\
\hline $\mathrm{R}^{2}$ & \multicolumn{3}{c}{0.803} \\
F-value & $24.328^{* * *}$ \\
Returns to scale & 1.094 \\
\hline
\end{tabular}

Source: Authors' calculation 2013; SE, standard error; ***, $\mathrm{p}<0.001 ; * * \mathrm{p}<0.01 ; *, \mathrm{p}<0.05$

\section{I nterpretation of the estimated model}

Day-old-chick cost $\left(\mathbf{X}_{\mathbf{1}}\right)$ : The regression coefficient of day-old-chicks was 0.196 which indicates that one percent increase in day-oldchick cost, on an average, would result in an increase in the gross return by 0.196 percent in Sonali chicken production farm, keeping other factors same.

Feed cost $\left(\mathbf{X}_{2}\right)$ : The regression coefficient of feed cost was 0.498 which implies that one percent increase in feed cost, on an average, would result in an increase in the gross return by 0.498 percent, holding other factors constant.

Labour cost $\left(\mathbf{X}_{\mathbf{3}}\right)$ : The regression co-efficient of labour cost was 0.075 and it was significant at 5 percent level of significance. It implies that 1 percent increase in expenditure on labour cost, would increase the gross return by 0.075 percent, other things remaining the same.

Veterinary and medicine cost $\left(X_{4}\right)$ : In case of veterinary and medicine cost, the regression coefficient was 0.081 and was significant at 10 percent level of significance. It revealed that 1 percent increase in money spent for veterinary cost, would increase in the gross return by 0.081 percent significantly, remaining other factors constant.

Electricity cost $\left(\mathbf{X}_{\mathbf{5}}\right)$ : The estimated regression coefficient for electricity was 0.058 and it was significant. This indicate that one percent increase in money value for electricity cost, would 


\section{Sonali chicken production}

increase in the gross return by 0.058 percent significantly in Sonali chicken production farm, keeping other factors same.

Litter cost $\left(\mathbf{X}_{\mathbf{6}}\right)$ : The regression coefficient of litter cost was 0.186 which revealed that one percent increase in litter cost, on an average, would increase the gross returns by 0.186 percent, holding other factors constant.

Coefficient of determination $\left(\mathbf{R}^{2}\right)$ : The values of the coefficient of multiple determination $\left(R^{2}\right)$ was 0.803 for the Sonali chicken production function which means that the explanatory variables included in the model explained 80 percent of the total variation in the gross return.

F-value: The F-value was 24.328 for Sonali chicken production which was highly significant at one percent level of significance implying that the equation was well fitted for explaining the variations of all included variables for total output of Sonali chicken production.

Returns to scale: The sum total of entire production coefficients (production elasticity) of the equation for Sonali chicken production was 1.094. This indicated that, if all the inputs specified in the production function were increased simultaneously by one percent, the gross returns to scale for Sonali chicken production would increase by 1.094 percent.

\section{Resource Use Efficiency}

To accomplish the profit maximization i.e., for efficient allocation of resources, one should use more of the variable resource so long as the value of the added product is greater than the cost of the added amount of the resource used in producing it. The standard way to examine such efficiency is to compare marginal value products (MVPs) with the marginal factor cost (MFCs) of each variable input. The optimum use of a particular input would be indicated by the condition of equality of MVP and MFC. If the ratio of MVP and MFC is greater than 1, the resource is sub-optimally used and the gross return could be increased by using more of the resource. If it is less than 1 , the resource is over used and the excess use of resource should be decreased to minimize the loss. The estimated geometric mean, coefficient and MVPs for different inputs for Sonali chicken production are showed in Table 7.

Table 7. Geometric mean, coefficient and marginal value products of different resource

\begin{tabular}{lccc}
\hline Variables & $\begin{array}{c}\text { Geometric } \\
\text { Mean (Antilog) }\end{array}$ & Coefficient & MVPs \\
\hline Intercept & 234522.9 & 11.951 & \\
$\mathrm{X}_{1}$ & 17665.8 & 0.196 & 2.602 \\
$\mathrm{X}_{2}$ & 99847.8 & 0.498 & 1.169 \\
$\mathrm{X}_{3}$ & 5766.8 & $0.075^{* *}$ & 3.051 \\
$\mathrm{X}_{4}$ & 7475.4 & $0.081^{*}$ & 2.541 \\
$\mathrm{X}_{5}$ & 2344.6 & $0.058^{* *}$ & 5.801 \\
$\mathrm{X}_{6}$ & 1282.6 & 0.186 & 34.011 \\
\hline
\end{tabular}

Source: Authors' calculation 2013; $X_{1}$, day-old-chick cost; $X_{2}$, feed cost, $X_{3}$, labour cost; $X_{4}$, veterinary cost; $X_{5}$, electricity cost; $X_{6}$, litter cost

In case of day-old-chick cost $\left(X_{1}\right)$, feed cost $\left(X_{2}\right)$, labour cost $\left(X_{3}\right)$, veterinary and medicine cost $\left(X_{4}\right)$, electricity cost $\left(X_{5}\right)$ cost and litter cost $\left(X_{6}\right)$ were greater than unity for Sonali chicken production indicating that these inputs were underutilized in the Sonali chicken production process and more return may be obtained by increasing the use of these resources. Resource use efficiency is shown in Table 8.

Table 8. Resource use efficiency

\begin{tabular}{lllllll}
\hline Particulars & $X_{1}$ & $X_{2}$ & $X_{3}$ & $X_{4}$ & $\left(X_{5}\right)$ & $X_{6}$ \\
\hline MVP & 2.602 & 1.169 & 3.051 & 2.541 & 5.801 & 34.011 \\
MFC & 1.00 & 1.00 & 1.00 & 1.00 & 1.00 & 1.00 \\
MVP/MFC & 2.602 & 1.169 & .051 & 2.541 & 5.801 & 34.011 \\
\hline
\end{tabular}

Source: Authors' calculation 2013

$X_{1}$, day-old-chick cost; $X_{2}$, feed cost, $X_{3}$, labour cost; $X_{4}$, veterinary cost; $X_{5}$, electricity cost; $X_{6}$, litter cost

From the above table, it emerges that the ratios of MVP and MFC of all the inputs were not equal to one. These inequalities indicate that the farmers in the study area were not able to show their efficiency in using all the resources. However, it can be concluded that if it is possible to get the ratios of MVP and MFC equal to unity, optimum use of resources could be possible for Sonali chicken farmer. 


\section{Constraints and opportunities}

Higher price and non-availability of feed, day-oldchick, medicine and vaccine, outbreak of diseases, non-availability of credit, inadequate training facilities, etc. are the major problems faced by the farmers in the study area. For developing the Sonali chicken farming more profitable, some suggestions were provided by the owners of the Sonali chicken farms (Table 9).

Table 9. Problems and probable solutions provided by farm owners

\begin{tabular}{lll}
\hline & Number & $\%$ \\
\hline Problems & & \\
High price and non-availability of feed & 47 & 78 \\
High price and non-availability of chick & 43 & 72 \\
High price of medicine and vaccine & 31 & 52 \\
Limited access of farmers to credit & 26 & 43 \\
Outbreak of diseases & 22 & 37 \\
Lack of education and training facilities & 20 & 33 \\
Inadequate supply of electricity & 41 & 68 \\
\hline Probable solutions & & \\
Increase feed availability and decrease price & 44 & 73 \\
Increase chicks availability and decrease price & 41 & 68 \\
Reduce the price of medicine and vaccine & 29 & 48 \\
Credit availability & 26 & 43 \\
Increase the education and training facilities & 18 & 30 \\
Adequate supply of electricity & 40 & 67 \\
\hline
\end{tabular}

Source: Field survey 2013

\section{Conclusion}

Sonali chicken farming on commercial basis is a popular endeavor in Bangladesh. The gross margin, net return and BCR of Sonali birds indicated that Sonali chicken farming is a profitable venture. Cobb-Douglas production function was estimated for the study to determine the effects of inputs on Sonali chicken production. The production function involved the inputs of feed cost, day-old-chick cost, labour cost, veterinary and medicine cost, electricity cost and litter cost. The coefficient of veterinary and medicine cost, electricity cost and labour cost were significant for different levels of degrees of freedom. Regarding resource use efficiency, the ratios of MVP and MFC of day-old-chick cost, feed cost, veterinary and medicine cost, electricity cost, labour cost and litter cost were greater than unity. The study identified some problems and constraints associated with Sonali chicken production and some solutions of these problems were given for improving the productivity and sustainability of Sonali chicken production.

\section{Acknowledgements}

Special thanks and appreciations are due to the Sonali chicken farmers in the study areas who provided the relevant information for conducting this research.

\section{References}

BER (Bangladesh Economic Review) (2011). Economic Advisers Wing, Finance Division, Ministry of Finance, Government of Peoples Republic of Bangladesh, Dhaka.

Chowdhury SD (2013). Opportunities and Challenges Facing Commercial Poultry Production in Bangladesh Eighth International Poultry Show and Seminar, WPSA-BB, Dhaka, Bangladesh.

Hossen MF, Siddque MAB, Hamid MA, Rahman MM, Moni MIZ (2012). Study on the Problems and Prospects of (Sonali) Poultry Farming in Different Village Levels of Joypurhat District in Bangladesh. Bangladesh Research Publications Journal, 6: 330-337.

Miazi OF, Miah G, Miazi MM, Uddin MM, Hassan MM, Faridhasan M (2012). Fertility and Hatchability of Fayoumi and Sonali Chicks. Scholarly Journal of Agricultural Science, 2: 83-86.

Saleque MA, Saha AA (2013). Production and Economic Performance of Small Scale Sonali Bird Farming for Meat Production in Bangladesh. Eighth International Poultry Show and Seminar, WPSA-BB, Dhaka, Bangladesh.

Zaman S, Siddique SU, Faruq MA, Pramani MR, Katoh M (2010). Composition and Trends of Homestead Agroforesty in Bangladesh: A case study in Dinajpur District. Journal of Sustainable Development, 6: 1-6. 